\title{
Violation Maxims of Main Characters in Keluarga Beti Comedy Series
}

\author{
Asrah Raihana ${ }^{1, *}$ Amrin Saragih ${ }^{2}$ Rahmad Husein ${ }^{3}$ \\ ${ }^{1}$ English Applied Linguistic Study Program, Postgraduate School, State University of Medan \\ ${ }^{2}$ State University of Medan \\ ${ }^{3}$ State University of Medan \\ *Corresponding author. E-mail: asrahraihan04@gmail.com
}

\begin{abstract}
This study deals with the violation maxims of main characters in Keluarga Beti comedy series. The objectives of the study were to investigate types of violation maxims, to describe realization of violation maxims, and to explain reasons of violation maxims. This research was conducted by qualitative design. The data were utterances of main characters which were violated. The data source of this research was taken from Keluarga Beti Comedy Series that was obtained from the video on YouTube. The finding of the data showed five types of violation maxim of characters in Keluarga Beti comedy series as violation maxim of quantity, violation maxim of quality, violation maxim of relation, violation maxim of manner, and violation maxim of combination. The most dominant type of violation maxim was violation maxim of quantity. The lowest violation maxim was violation maxim of combination. It influenced by much information than is required, so that it causes bad communication for listener.
\end{abstract}

Keywords: Violation Maxims, Main Characters, Comedy, Keluarga Beti Comedy Series.

\section{INTRODUCTION}

People use language as communication. Communication is simply the act of transferring information from one place to another. People use many variations in communicating in order to share their feelings and ideas such as verbal and nonverbal communication. Communication makes information can easily be delivered from the speaker to listener. Communication requires that the communicating parties share an area of communicative commonality.

The speakers and listeners always make efforts to contribute efficiently when they partake in conversation in order to achieve the purpose. In achieving the purpose, the conversation should have direction. Grice considered this by proposing conversational maxims to set the mechanism of conversation in order to make the speaker and listener understand each other based on which people interpret others' utterances. Conversational maxim is a set of rule in conversation between speaker and listener as says that conversational maxims are the areas in which conversational partners cooperate [1]. The speaker and listener cooperate during conversation by delivering his/her intention for speaker and interpreting the speaker's intention for the listener so that the communication becomes effective.

Effective communication only occurs if interlocutors give the appropriate contribution in talk exchange. Sometimes the listener misunderstands what the speaker says. This can occur if the speaker does not say something directly what he/she means, when the speaker does not say what he/she means, it means he/she implies the meaning. It can be understand if the listener can misunderstand the speaker's utterance because sometimes what the speaker means is different with what speaker says. Make your conversational contribution such as is required, at the stage at which it occurs, by the accepted purpose or direction of the talk exchange in which you are engaged. Four conversational implicature known as conversational maxims to explain the link between utterances and what was understood from them in order [4]. The four maxims are maxim of quantity (informative), maxim of quality (truthful), maxim of relation (relevant), and maxim of manner (clear).

Successful communication can occur by means of obeying the maxim, there is still a problem when a speaker does not follow the rules of maxims. Generally, a speaker has particular purposes in braking maxim that he or she wants interpreting to achieve. There are four breaking maxims developed, they are flouting, infringing, opting out, and suspending [8]. From the four breaking maxims, violating is one of used failure that occurred in conversation every day. If speakers do not purposefully fulfill certain maxim, there will be maxim violation.

Conversational maxims occur in the conversations in every situation of human life. The definition of 
humor is something that aims to make a person laugh or smile. It is as a condition that can cause people laugh in everyday life [7]. However, humor appears not just as an entertainment but also has characteristics or form and function of its own.

The phenomenon of the humor serves in several media such as book, television, radio and even online media (social media). Social media such as Facebook, Twitter, blogs, as well as the photo and video-sharing sites YouTube, and Instagram. One of them is Keluarga Beti in which many utterances happen among the characters. This comedy series was played by Arif Muhammad. This series appeared on YouTube in 2013. The reason is that Arif Muhammad does not only play one character, but all the characters in this series. This series tells the story of life, especially Beti's Family in their daily lives, with her friends and neighbors. The utterance make in many conversations involve some main characters (Mak Beti, Beti, Merlin, Marta, Joshua, Wak Keling, and Hardi) in Keluarga Beti. This series tells how the life of child and his mother who still live in the village.

While researcher watches Keluarga Beti Series, the researcher finds the conversation there. The main characters in the series were violence communication to make interaction among the speaker from each other. The preliminary data which takes from the conversation happens in Mak Beti Series. This utterance follow violating maxim in it:

B : Iiiisss... gak ada yang lewat lo lin. Berapa lama lagi kita nunggu ini? Males kali aku kek gini lah.

(Iiiissss... there's no public transportation coming through. How much longer we need to wait? I hate witing like this).

Mrl : Sabar kau! Angkot disini lewatnya satu-satu. Macem gak tau aja kau jalan angker ini.

(Be patient ... the public transportation here only passes through one by one. You knew already this road is haunted). (Title: Kabar Duka Merlin: $15^{\text {th }}$ December 2020)

Merlin and Beti are waiting for the public transportation in the public transportation stop. But the public transportation was very long to come there. Beti ask to Merlin about that situation, the reason why is the public transportation did not come yet, whereas they have been waiting a long time. In the conversation above shows Merlin in the example of preliminary data, violating maxim of quantity happens when a speaker does not contain information that is really needed by the speech partner [2]. Likewise, if the speech was contains excessive information. The speaker gives more information (overstating). The statement from Mrl covers the public transportation that did not passed away yet. So, the reason of Mrl's statement was hiding the truth.

The reason for choosing the violation maxims of main characters in Keluarga Beti comedy series because comedy usually contains humor or unusual language, sentences, phrase, word that contain the violation maxim. This comedy series relate to occurrences of the different situation of violation maxim in conversation in another research.

\section{REVIEW OF LITERATURE}

The purpose of cooperative principle is to communicate something in proper contribution. People basically try to cooperate in conversation to construct a meaningful conversation [4]. Interlocutors should converse in a maximal efficient, rational and cooperative way with speak sincerely relevantly, and clearly [6].

Violating happens in order to deceive a hearer with letting the hearer only knows the surface meaning of an utterance. Saying something which is not true is an example of violating [2]. Violation is the condition where the speakers do not purposefully fulfill certain maxim [9[. There are four sub-principles; maxim of quantity, maxim of quality, maxim of relevance and maxim of manner [4[. Interlocutors try to understand contributions to violated maxims informative, truthful, relevant, and clear. Once these contributions are broken, interlocutors try to interpret, induce, or search for inferences of conversational implicature [5].

Violating can also happen in four sub-principles of maxim. There are violating towards maxim of quantity, quality, relation, and manner [2].

If a speaker violates the maxim of quantity, they do not give the hearer enough information to know what is being talked about, because they do not want to hearer to know the full picture [2]. The speaker is not implying anything; they are 'being economical with the truth'. For example:

Petter : Does your dog bite?

Receptionist : No

Petter : (Bends down to stroke it and gets bitten) ow! You said your dog doesn't bite!

Receptionist : That isn't my dog

Petter sellers' film in which the Pink Panther asks a hotel receptionist about a little dog beside the desk. The receptionist knew that he was talking about the dog in front of her and not her dog at home, yet the intentionally did not give him enough information, for reasons best known to herself.

Speaker can violate the maxim of quality by not being sincere and tend to give wrong information to a hearer. Violating towards maxim of quality is a situation where a speaker is not sincere and gives wrong information to a hearer, which can be said as lie [2]. For example:

Husband : How much did that new dress cost, darling?

Wife : Less than the last one

Here, the wife covers up the price of the dress by not saying how much less than her last dress. The wife, when asked 'How much did that new dress cost, darling?' could have violated maxim of quality by not being sincere, and giving him the wrong information: "thirty-five pounds". In the example above, knew that 
the young man did not realize that he had failed the interview because of his performance, and if he knew that the young man would believe that it was the size of the college that was wrong for him, then he could be said to be telling a lie, because he was violating the maxim of quality.

Violating in maxim of relation happens when speaker try to distract and change the topic to another one [2]. Violating towards maxim of relation happens when a speaker change the topic to avoid the answer or topic that brought by other interlocutors in conversation. For example:

Husband: How much did that new dress cost, darling?

Wife : I know, let's go out tonight.

In answer to 'How much did that new dress cost, darling?" the wife could have answered violating the maxim of relation, in order to distract him and change the topic: "I know, let's go out tonight.

Violating maxim of manner happens when someone gives obscure reference and vague reference in order to avoid a brief and orderly answer in a conversation [2]. For example:

A : What would the other people say?

B : Ah well I don't know I wouldn't like to repeat it because I don't really believe half of what they are saying. They just get a fixed into their mind.

Her 'half of what they are saying' is an obscure reference to the other people's opinion, and a fixed thing contains a general noun containing vague reference. She may be using these expressions to avoid giving a brief and orderly answer, for the moment.

Comedy is supposed to make us respond in a certain way, e.g. smile, giggle, laugh. Arguably, this is the chief defining characteristic of comedy films. However, we do not have definite answers to why we smile and why we laugh. Of course, one could argue, that we laugh and smile because evolution perpetuates behaviors that results in social bonding in humans [3]. Indeed, many researchers have argued that laughter and amusement have more to do with social interaction than with the structure of jokes or private physiological responses.

Keluarga Beti comedy series is a comedy series made by a content creator in YouTube. There are many videos containing jokes, fun and something that have a value such message for audience. This series is sketch, is shorter version of sitcom (scripted dialogue creating a thematic situation) practiced and typically performed live.

The following of the characters that exist in this series; Mak Beti, Beti, Martha, Merlin, Joshua, Wak Keling, and Hardi.

\section{RESEARCH METHOD}

This research will be conducted by using qualitative descriptive design. This study will be concerned to violating maxim in Comedy Series. The data were utterances which consist of sentence, phrase, and word of Main Characters in Keluarga Beti Comedy
Series. the utterances from Mak Beti (MB), Beti (B), Merlin (Mrl), Marta (Mrt), Wak Keling (WK), and Hardi $(\mathrm{H})$. The sources of data were from video by Keluarga Beti Comedy Series in YouTube channel. To collect the data, documentary technique will be applied. The data were browsed and downloaded from the YouTube so that download videos about Keluarga Beti Comedy Series.

\section{RESEARCH FINDINGS}

After analyzing the five series of Keluarga Beti Comedy Series, the researcher found out that all of type violation maxims occurred in the series.

Table 1. Types Violation Maxims of Main Characters in Keluarga Beti Comedy Series

\begin{tabular}{cccc}
\hline No & $\begin{array}{c}\text { Types of } \\
\text { Violation } \\
\text { Maxims }\end{array}$ & Total & $\begin{array}{c}\text { Percentage } \\
(\%)\end{array}$ \\
\hline 1 & Quantity & 29 & 35.80 \\
2 & Quality & 8 & 9.87 \\
3 & Relation & 10 & 12.34 \\
4 & Manner & 28 & 34.56 \\
5 & Combination & 6 & 7.40 \\
& Total & 81 & 100 \\
\hline
\end{tabular}

The table showed violation maxims was mostly found in quantity (29) than manner (28), relation (10) quality (8), and combination (6). It meant that violation maxims dominantly violated in quantity of main characters in Keluarga Beti Comedy Series. The violation maxims of quantity occurred dominantly by main characters. It was meant that the main characters were given the information than is required.

$\underline{\text { Data } 1}$

WK : Ya udah mak Bet ya, gerak lah aku dulu (That's it yaeah mak Bet, I'm going to now)

MB

: Iya-iya wak, yang semangat ya wak ya. Yang sabar wak. Ya Allah kasian kalilah wak keeling itu bertubi-tubi cobaan dia di dunia ini. Semoga wak keeling diberi kesabaran dan keselamatan aamiin. Mak Beti keeling keliling. Eh kok aku ngomong kek gitu pulak lah paok ini.

(Yeah Wak. Fighting yeah wak yeah. Be patient Wak. Yah Allah unfortunate you are Wak Keling. She has many life's problem in this world. May Wak Keling will be given full of patience and salvation Aamiin. Mak Beti Keling is shop around. Eh, why i said like this yeah, stupid to me).

In the data above, the response of MB gave more information than is required to WK. MB give too much explanation. WK statement's want to go away, but MB's response by adding more information related to give a pray for the situation happened. Therefore, it can be conclude that the utterances above were violation maxim of quantity. 
Data 2

HF : Berapa bayarnya?

(How much is it?)

MB : Gak tau pokoknya bayar juga. Mau berapa puluhan juta bisa ku bayar. Ambil semua bill nya!

(I don't know. But, as long as you know I can pay tens of million. You take all bills!)

$\mathrm{H}$ : Siap. Tinggal bayar. Loh Mak Beti mana?

(Alright, I will pay. Where is Mak Beti?)

MB : Dadahh dadahh

(Bye bye)

MB said if she will pay a car with the high price. Then MB statement show violated maxim of quality by not being sincere and giving him wrong information. The utterance of MB above can be categorized as violate maxim of quality. $\mathrm{MB}$ did not give true information, because of her financial is low and she knew that can't be able to pay a car, then she could be said to be telling a lie.

$\underline{\text { Data } 3}$

Mrl : Entah lah. Kenapa gak kau tanya tadi langsung? Mesti kali kau tanya sama aku.

(Who knows. Why did you ask him directly? Would you ask me).

J : Ah nanti tersinggung pulak Beti. Kau taulah kadang dia sensitive

(Ah Beti will be offended later. You know that sometimes she is sensitive).

Mrt : Hah Beti positif? Beti hamil? Yee bentar lagi Beti hamil Beti hamil melahirkan, Martha punya keponakan yee yee Beti hamil. Hamil itu apa wee?

(Huh Beti positive? Beti pregnant? Yeah soon Beti is pregnant Beti is pregnant gives birth, Martha has a niece, yeah yeah Beti is pregnant. What is pregnancy wee?).

The response given by Mrt was unrelated with J's statement. J's statement should be response by saying something a reason which show about someone was unusual style, but Mrt instead of she is positive and pregnant. Therefore, it can be categorized to violation maxim of relation as $\mathrm{J}$ changed the topic abruptly.

\section{$\underline{\text { Data } 4}$}

Beti : Ya aku lah yang pintar, kok kau pulak, gila kau lah

(Yeah, I am the clever one not you. Crazy you are).

Mrt : Ya udah sukakmu lah, ko ambil nah kepintaranku, nyah nyah ambil, aku udah banyak.

(Alright, up to you. Just take my intelligence, nah nah because I've got a lot)

The response of Mrt above violated maxim of manner by obscure reference to B's statement. She may be using these statements to avoid giving a brief and orderly answer for a moment by saying something did not happen for people. She did not give clearly statement that make confused. $\underline{\text { Data } 5}$

Mrl : Bet, kau tau umi punya anak?

(Bet, did you know that umi has a child?)

B : Taulah, Fahri namanya kan Lin? Semalam itu dibantunya aku ngangkat gallon sampek rumahku, is baik kalli Fahri ah, persis kali ini kayak bapakku.

(I know, Fahri's name is Lin? Yesterday, I helped him to lift the gallon to my house, ihhh he's very well ah and he looks like my dady).

The utterance above can be concluded as violation mxim of combination. B answered Mrl's question by given more information than is required. Mrl only asked about special someone for them with the specific thing because some of girl in there like him. B's answered was much information even explanation unclear with the question. B saying like my daddy is an obscure reference to Mrl's question. Therefore, it can be categorized as violation maxim of quantity and manner.

\section{CONCLUSION}

It is found that all types and two combination of violation maxim in Keluarga Beti Comedy Series. They are violation maxim of quantity, violation maxim of quality, violation maxim of relation, violation maxim of manner, violation maxim combination of quantity and manner. the dominant types violation maxims is violation maxim of quantity. The violation maxim happened in a lack of communication each other in conversation. It caused by give much information, lie information, changing information and unclear information.

\section{AUTHORS' CONTRIBUTION}

The findings of this study are expected to add new knowledge in pragmatic. In addition, this study found new something in a case. Hopefully, other study should be find out more types of violation maxims in other case of study, advisable for speaker and listener in understanding the violation maxims and following the rules of maxims in order to create effective and successful communication. Human must be good in a situation between speaker and listener.

\section{ACKNOWLEDGEMENTS}

The writer would like to express her gratitude to greatest advisers Prof Dr. Amrin Saragih, M.A, Ph.D and Dr. Rahmad Husein, M.Ed who have guided her in the during the process of the research writing with all of guidance, advices, and suggestions to finish the research as well.

\section{REFERENCES}

[1] Chapman, S. (2000). Philosophy for Linguistics. London: Routledge.

[2] Cutting, J. (2002) Pragmatics and Discourse: A Resource Book for Students. New York: Routledge. 
[3] Eitzen, D. (2005). The Duties of Documentary in a Post-Truth Society. Cognitive Theory and Documentary.

[4] Grice, H. P. (1975) Logic and Conversation. Berkeley: University of California.

[5] Leech, G. N. (1980). Principles of Pragmatics. London: Longman.

[6] Levinson, S. C. (1983). Pragmatics. Cambridge: Cambridge University Press.

[7] Ross, A. (2005). The Language of Humour. Taylor and Francis e-Library.

[8] Thomas, J. (1995). The Meaning of Interaction: An Introduction to Pragmatics. New York: Longman.

[9] Tupan, A. H and Natalia, H. (2008). The Multiple Violations of Conversational Maxims in Lying Done by the Characters ini Some Episode of desperate Housewives. 10(1): 63-78. University Press. 